\title{
DISKRIMINASI KELAMIN PADA IKAN TUNA SIRIP KUNING, Yellowfin tuna MENGGUNAKAN ANALISIS DOT BLOT DAN ELISA
}

\author{
Gusti Ngurah Permana*), Jhon Harianto Hutapea*), dan Gavin Patridge*) \\ *) Balai Besar Penelitian dan Pengembangan Budidaya Laut \\ Jl. Br. Gondol Kec. Gerokgak Kab. Buleleng, Kotak Pos 140, Singaraja, Bali 81101 \\ E-mail: gustipermana@gmail.com \\ **) Senior Research Scientist of Aquaculture Research and Development at \\ Challenger Institute of Technology Centre for Applied Aquaculture Research \\ Australia
}

(Naskah diterima: 14 April 2013; Disetujui publikasi: 3 Maret 2014)

\begin{abstract}
ABSTRAK
Pemahaman tentang penentuan jenis kelamin dalam populasi induk merupakan hal yang sangat penting bagi keberhasilan program pembenihan. Pengukuran reaksi antibodi dan aktivitas hormon testosterone, serta estradiol adalah metode dengan potensi yang secara akurat dapat menentukan jenis kelamin ikan tanpa mematikan ikan. Tujuan penelitian ini adalah untuk mengetahui akurasi metode dot blot dan ELISA dengan 11-ketotestorsterone (11-KT) yang tersedia secara komersial EIA-kit untuk membedakan jenis kelamin ikan tuna sirip kuning. Hasil analisis menunjukkan bahwa metode dot blot menghasilkan ekspresi vitelogenin tampak jelas pada individu betina dan efek plasma terlihat transparan, jika dibandingkan dengan individu jantan. Interpretasi dari metode ini memerlukan pengalaman dan keahlian dalam akurasi pembacaan hasil. Aktivitas hormon 11-KT dengan sampel klip sirip dan plasma memberikan hasil yang baik dengan aktivitas hormon terlihat jelas.
\end{abstract}

KATA KUNCl: dot blot, vitelogenin, ketotestosteron, estradiol, ikan tuna sirip kuning

ABSTRACT: Sex discrimination of yellowfin tuna by using dot blot and elisa analysis. By: Gusti Ngurah Permana, Jhon Harianto Hutapea, and Gavin Patridge

Understanding of sex differentiation of fish population is importance to support breeding program. Parameters of antibody reaction and hormone activity of testosterone and estradiol are usefull tools to detect sex discrimination of fish. The study was conducted to determine the accuracy of dot blot and ELISA method with a 11-ketotestorsterone and estradiol hormone available ElA-kit commercially. The results of dot blot produced apparent vitellogenin expression in female individuals and the effect of plasma was transparent, when it was compared to male individuals. Interpretation of this method requires an experience and expertise in reading accuracy. Activity of the hormone 11-KT with fin clips and plasma samples had a good results.

KEYWORDS: dot blot, vitelogenin, ketotestosteron, estradiol, yellowfin tuna 


\section{PENDAHULUAN}

Secara sepintas untuk membedakan ikan jantan dan betina memang mudah, tetapi pada kenyataannya tidaklah demikian. Beberapa spesies ikan di perairan pantai dapat secara jelas terlihat perbedaan secara morfologi antara individu jantan dan betina. Pada spesies ikan tertentu seperti ikan tuna (Thunnus sp.), ikan bandeng (Chanos chanos), dan kelompok ikan kerapu (Epinephelus spp., Cromileptes altivelis) sangat sulit dibedakan jenis kelaminnya. Kajian ini sangat penting nantinya diterapkan dalam pembenihan sehingga para pembudidaya ikan tahu benar bahwa ikan yang dibenihkan mempunyai perbandingan yang optimum antara jantan dan betina. Lebih lanjut menurut Suhendrata \& Wahyono (1987), diketahui bahwa rasio kelamin ikan cakalang jantan dan betina adalah 1,07:1,00. Nilai tersebut secara umum hampir sama dengan ikan tuna di alam pada umumnya.

Pemahaman tentang rasio jenis kelamin dalam populasi induk merupakan hal yang sangat penting bagi keberhasilan program manajemen induk ikan tuna sirip kuning yang dipelihara di tangki beton. Metode konvensional dengan pengamatan morfologi yang digunakan untuk penentuan jenis kelamin induk tidak cocok untuk ikan tuna karena ukurannya yang besar dan kesulitan dalam penanganan dan anestesi ikan. Penentuan status reproduksi merupakan persyaratan utama untuk setiap pengelolaan program pembenihan.

Vitelogenin (VTG) telah luas digunakan dalam budidaya perikanan sebagai indikator kematangan seksual (Bon et al., 1997; Mosconi et al., 1998). Pengukuran reaksi antibodi dan aktivitas hormon testosteron dan estradiol adalah alat dengan potensi besar untuk menentukan jenis kelamin ikan tanpa mematikan ikan. Metode ini berpotensi dapat digunakan pada ikan khususnya bagi induk yellowfin tuna, yang ditangkap dengan ukuran $(<10$ $\mathrm{kg}$ ) atau dilakukan pengambilan sampel sebelum ditransfer ke tangki pemeliharaan induk.

Tujuan dari penelitian ini adalah untuk mengetahui jenis kelamin pada ikan tuna sirip kuning yang dipelihara di tangki beton dengan metode dot blot, serta aktivitas hormon 11ketotestorsterone dan estradiol. Selain itu, untuk mengetahui akurasi ketiga metode tersebut untuk membedakan jenis kelamin ikan tuna kuning.

\section{BAHAN DAN METODE}

Sampel yang dipergunakan untuk analisis menggunakan ikan mati yang sudah diketahui atau dikenali jenis kelaminnya berdasarkan keragaan gonad dengan analisis visual dan histologi. Sampel yang diambil adalah darah, klip sirip, dan otot punggung. Plasma dipisahkan dari sel-sel darah merah melalui sentrifugasi sebelum dianalisis. Sampel otot daging diambil dengan menggunakan 'genetag biopsi hook'. Pada hari yang sama, enam ikan kecil mulai ukuran 6,6-12,0 kg yang ditransfer dari tangki aklimasi ke tangki induk diambil sampel klip sirip dan biopsi otot kecil dengan menggunakan 'hook genetag biopsi'.

\section{Dot Blot}

Antibodi primer untuk analisis dot blot yang digunakan sama dengan anti blue fin tuna Zrp (zona radiata protein) (Bonn et al., 2002). Metode ini diperkenalkan oleh Profesor Christopher Bridges dari Institute for Zoology, Heinrich Heine University Dusseldorf, Jerman di Balai Besar Penelitian dan Pengembangan Budidaya Laut, Gondol. Persiapan tube reaksi dengan memasukkan $200 \mu \mathrm{L}$ buffer (Tris HCL $0,1 \mathrm{~mol} / \mathrm{L} ; \mathrm{pH} 6,8$ ) ke dalam setiap tube dan ditambahkan $1 \mathrm{~mL}$ Pefabloc (1 mM). Selanjutnya ekstraksi sampel dengan menimbang sebanyak 0,2 g klip sirip, dimasukkan ke dalam tube reaksi tadi, dan dihancurkan pakai pistil. Inkubasi selama 60 menit kemudian sentrifuse kecepatan $14.000 \mathrm{rpm}, 4^{\circ} \mathrm{C}$ selama 15 menit. Supernatan merupakan sampel yang dipergunakan untuk analisis. Pengenceran dari sampel hasil ekstraksi menggunakan Tris $\mathrm{HCL}$. Loading sampel dilakukan dengan menambahkan $1 \mu \mathrm{L}$ sampel, $1 \mu \mathrm{L}$ standar dan $1 \mu \mathrm{L}$ Tris HCL pada kertas Nitrocellulosembrane membran dan dikeringkan selama 15 menit. Blocking dilakukan dengan memasukkan $1,5 \mathrm{~mL}$ blocking solution (rotiblock 1:10) dan diinkubasi selama 30 menit. Antibodi primer ( $1^{\text {st }}$ antibody/rabbit- $\alpha$-tuna), antibodi Vtg (vitelogenin) 1:7.500 dan antibodi Zrp 1:15.000, keduanya diencerkan dengan PBS dan diinkubasi selama 60 menit pada suhu ruang. Selanjutnya pencucian (washing) menggunakan buffer pencuci (washing buffer) terdiri PBS (phosphate buffer saline) $+0,05 \%$ Triton $X+0,1 \%$ Tween20. Washing buffer dibuang dan diulang $2-3$ kali. Pada proses ini dilakukan shaker sehingga tercuci sempurna. Kemudian ditambahkan antibodi sekunder ( $2^{\text {nd }}$ antibody/goat- $\alpha$ rabbit); 1:15.000 diencerkan dengan PBS + 
Tween- 20 diinkubasi selama 30 menit dalam suhu ruangan dan selanjutnya cuci dengan miliQ water. Pewarnaan (coloration) menggunakan Nitro blue tentrazolium (NBT) diinkubasi selama lima menit dalam kondisi gelap, setelah selesai dicuci dengan miliQ water. Kontrol negatif terdiri atas buffer $(0,1 \mathrm{M}$ PBS; $\mathrm{pH} 7,4$; 0,05\%Tween- 20; dan $27 \mathrm{mM} \mathrm{KCL),} \mathrm{sedangkan}$ positif kontrol dari vitelogenin standar atau Zrp pada konsentrasi $100 \mu \mathrm{g} \mathrm{mL}^{-1}$. Pembacaan pola gambar hasil staining diinterpretasikan sebagai +++ (sangat jelas/ cerah), ++ (jelas), + (kurang jelas), \pm (tipis), dan - (tidak aktif).

\section{ELISA Hormon}

Ekstraksi hormon dari klip sirip, daging, dan plasma dilakukan dengan dietil eter. Hormon dalam plasma diukur secara langsung dalam sampel yang diencerkan dengan buffer EIA pada rasio 10:490, 50:450, dan 100:400. Kadar hormone 11- ketotestosterone dan estradiol diukur menggunakan ELISA reader yang tersedia secara komersial (Cayman Chemical Company, katalog No. 582751). Prosedur preparasi reaksi mengikuti manual yang ada dalam kit.

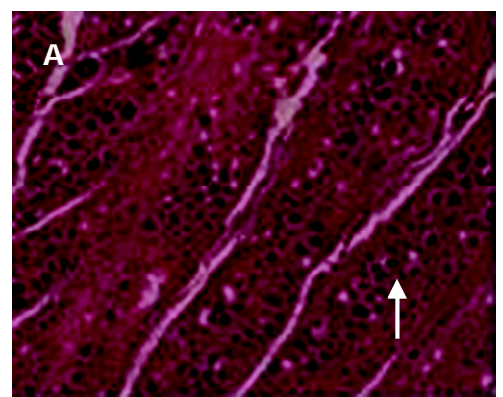

Betina (Female)

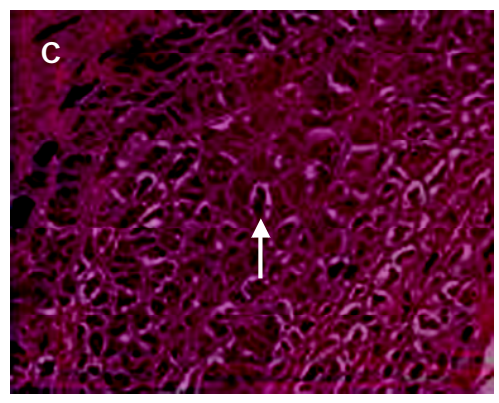

Betina (Female)

\section{HASIL DAN BAHASAN}

\section{Karakter Histologi Gonad}

Pengamatan jenis kelamin pada awalnya dilakukan berdasarkan analisis histologi gonad ikan yang mati (Gambar 1). Pada Gambar 1A teridentifikasi ikan tuna dengan jenis kelamin betina di mana oocytes primer (germ cells) terlihat dan perkembangan lipatan ovigorous dari gonad. Ikan tuna sirip kuning teridentifikasi jantan di mana terlihat granular cells yang menyerupai spermatogonia yang berkembang (Gambar 1B). Sedangkan Gambar 1C adalah betina di mana ovary dengan oocytes pada chromatin nucleolus dan fase perinucleolus, pewarnaan yang agak gelap adalah nucleus yang dikelilingi oleh sitoplasma. Histologi sampel pada Gambar 1D adalah jantan di mana terlihat granular cells pada bagian kiri menyerupai spermatogonia yang berkembang.

Berdasarkan hasil analisis histologi pada Tabel 1, terlihat bahwa pada sampel 1A secara visual dari gonad terlihat adalah jantan, namun demikian pada kenyataannya adalah betina yang ditunjukkan dari oocytes primer (germ

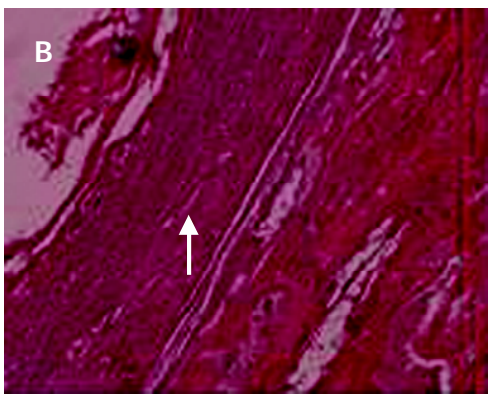

Jantan (Male)

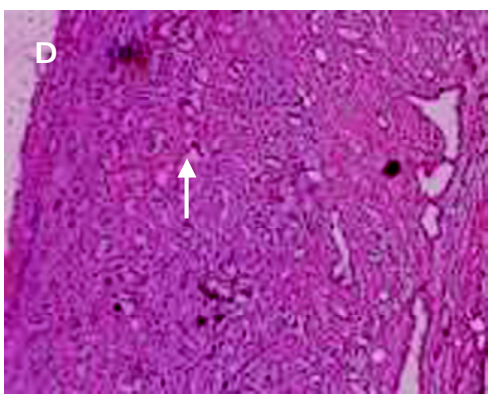

Jantan (Male)

Gambar 1. Irisan histologi gonad induk ikan tuna sirip kuning (pembesaran 200x)

Figure 1. Histology section of broodstock candidate of yellowfin tuna (200x magnification) 
Table 1. Bobot badan dan panjang cagak sampel yang dipergunakan untuk analisis histologi Table 1. Body weight dan fork length of samples used to histology analysis

\begin{tabular}{cccccccc}
\hline $\begin{array}{c}\text { Kode } \\
\text { sampel } \\
\text { Sample } \\
\text { code }\end{array}$ & $\begin{array}{c}\text { Tanggal } \\
\text { kematian } \\
\text { Date at } \\
\text { death }\end{array}$ & $\begin{array}{c}\text { Bobot } \\
\text { badan } \\
\text { Body } \\
\text { weight } \\
\text { (kg) }\end{array}$ & $\begin{array}{c}\text { Panjang } \\
\text { cagak } \\
\text { Fork } \\
\text { length } \\
\text { (cm) }\end{array}$ & $\begin{array}{c}\text { Hati } \\
\text { Liver } \\
(\mathbf{g})\end{array}$ & $\begin{array}{c}\text { Gonad } \\
\text { Gonad } \\
(\mathbf{g})\end{array}$ & $\begin{array}{c}\text { Jenis kelamin } \\
\text { saat mati } \\
\text { Sex at death }\end{array}$ & $\begin{array}{c}\text { Histologi } \\
\text { Known of } \\
\text { histology }\end{array}$ \\
\hline 1A & $23 / 1 / 2010$ & 9.25 & 78.5 & 62.98 & 9.32 & Jantan (Male) & Betina (Female) \\
1B & $23 / 1 / 2010$ & 4.35 & 61 & 32.59 & 0.92 & Jantan (Male) & Jantan (Male) \\
1C & $23 / 1 / 2010$ & 8.95 & 77 & 60.5 & 31.14 & Betina (Female) & Betina (Female) \\
1D & $23 / 1 / 2010$ & 4.1 & 58.5 & 26.12 & 1.93 & Jantan (Male) & Jantan (Male) \\
\hline
\end{tabular}

Keterangan (Note):

Identifikasi secara morfologi dari gonad jantan (putih susu) dan betina (kuning keputihan dengan tekstur lebih kasar) (Identification morphologically from male gonad (white milk) and female (yellow with texture more rugged))

cells) terlihat dan perkembangan lipatan ovigorous dari gonad. Pada sampel yang lain hasil identifikasi saat mati sesuai dengan hasil histologi.

\section{Dot Blot}

Penentuan jenis kelamin berdasarkan reaksi antibodi ini dapat digunakan pada ikan yang telah menunjukkan aktivitas hormon dan pembentukan vitelogenin (Sauca et al., 2001). Antibodi primer untuk dot blot analisis yang digunakan sama dengan rabbit anti blue fin tuna Zrp (zona radiata protein) (Bonn et al., 2002; Desantis et al., 2005). Metode dot blot mengikuti prosedur yang dikembangkan oleh Sauca et al. (2001). Ekspresi vitelogenin akan nampak jelas terekspresi pada individu betina dan efek plasma terlihat transparan jika dibandingkan pada individu jantan (Gambar 2).

\section{Estradiol}

Aktivitas hormon estradiol pada ikan tuna sirip kuning memperlihatkan hasil yang kurang baik. Dari semua sampel aktivitas hormon ini tidak terlihat jelas (Gambar 3). Hal ini dapat disebabkan karena konsentrasi Estradiol- 17 $\beta$ dalam induk betina masih sedikit, artinya pembentukan vitelogenin belum sempurna. Selain itu, menurut Zai rin (2000), menyatakan bahwa pola konsentrasi estradiol- $17 \beta$ pada ikan akan meningkat sesuai dengan pola pemijahannya.

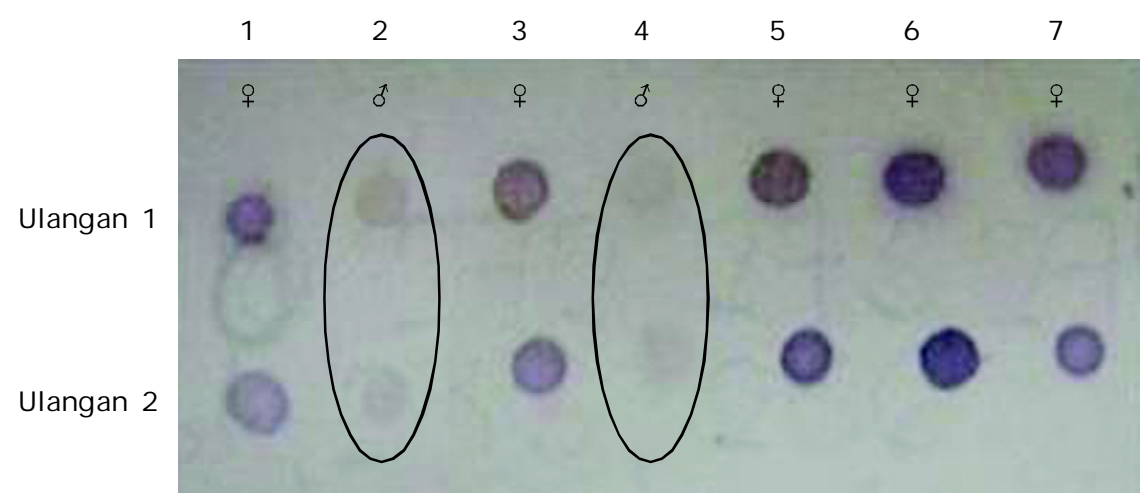

Gambar 2. Perbedaan ekspresi warna pada individu jantan dan betina menggunakan analisis dot blot dengan antibodi rabbit anti bluefin tuna

Figure 2. Different colouration of female and male of yellowfin tuna using dot blot analysis with antibody rabbit anti bluefin tuna 

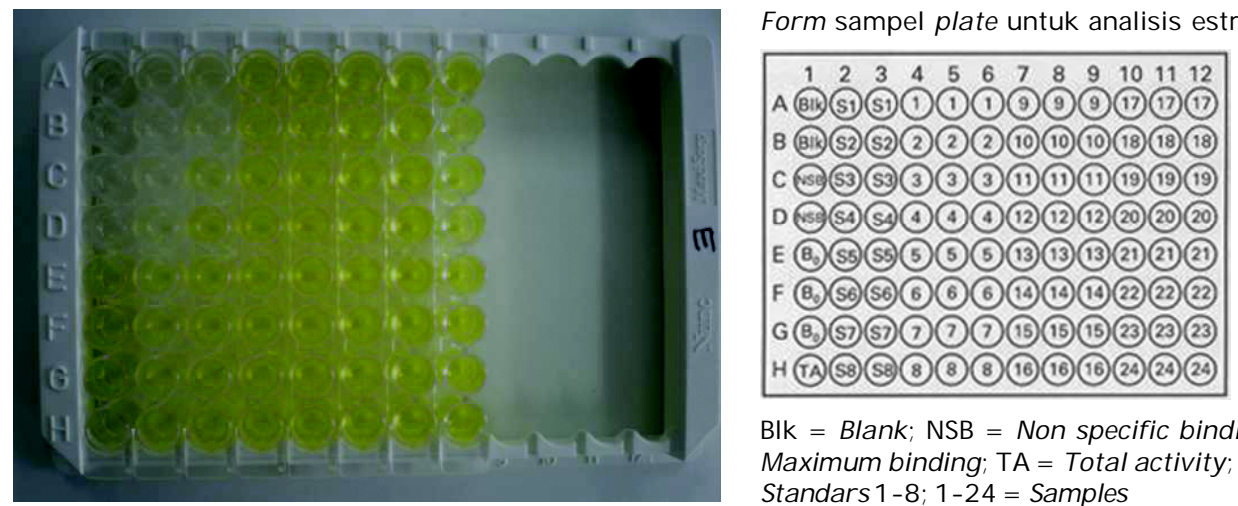

Blk = Blank; NSB = Non specific binding; $B=$ Maximum binding; $\mathrm{TA}=$ Total activity; $\mathrm{SI}-\mathrm{S} 8=$ Standars 1- 8; 1- 24 = Samples

Gambar 3. Reaksi warna pada plate sampel aktivitas hormon estradiol

Figure 3. Colouration pattern of estradiol activity

\section{1- Ketotestosteron}

Hasil uji 11-KT pada biopsi otot, klip sirip, dan darah diketahui memberikan hasil yang berbeda. Aktivitas hormon 11- KT dalam sampel otot yang diambil dengan kait biopsi gene tag mempunyai akurasi yang rendah. Hal ini dapat disebabkan karena jumlah otot daging yang diambil melalui metode ini tidak cukup untuk mengekstrak 11-KT, sehingga hasilnya tidak mendapatkan nilai positif. Lain halnya aktivitas 11- KT yang diekstrak dari sampel plasma darah ternyata dapat mengidentifikasi kelamin jantan yang diencerkan 50:450, tetapi pengenceran dengan 10:490 terlalu encer untuk mendeteksi 11-KT (Gambar 4).

Hasil analisis hormon 11- KT menggunakan klip sirip memberikan hasil yang baik dengan

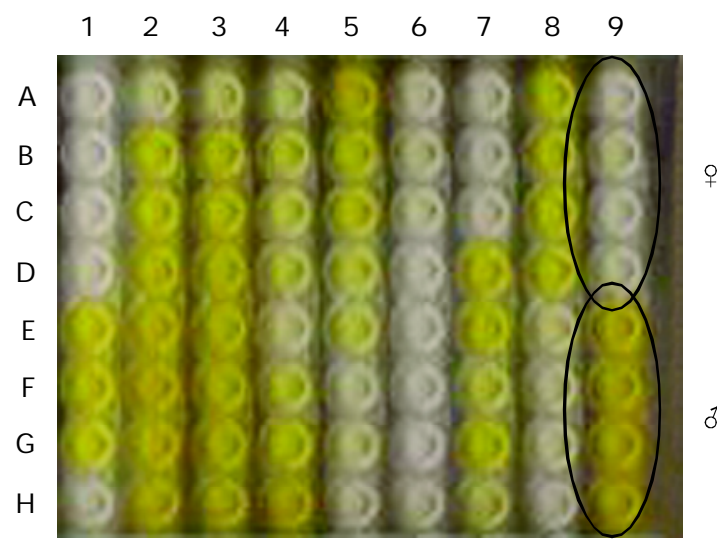

aktivitas hormon terlihat jelas. Semua calon induk yang akan dipindah ke tangki induk telah diberi tagging dan diambil fin klip untuk analisis 11- KT dan mt- DNA. Namun demikian belum dapat disimpulkan ukuran minimum ikan yang dapat terdeteksi hormonal 11- KT secara akurat. Hasil analisis hormon 11-KT yang diekstrak dari fin klip pada ikan tuna sirip kuning yang dipelihara di tangki induk terlihat pada Tabel 2.

Berdasarkan hasil analisis ELISA (Tabel 2 ), perkiraan jumlah induk betina yang ada di tangki pemeliharaan adalah 11 ekor, sedangkan jumlah induk jantan yang terindentifikasi adalah 15 ekor. Hasil kajian ini sangat penting diterapkan dalam breeding dengan mengetahui perbandingan yang optimum antara jantan dan betina pada tangki pemeliharaan induk.

Gambar 4. Reaksi warna pada plate sampel aktivitas hormon 11-ketotestosterone

Figure4. Colouration of samples 11 Ketotestosteron activity 
Tabel 2. Data analisis ELISA induk ikan tuna sirip kuning selama pemeliharaan Table2. Elisa samples of yellowfin tuna broodstock in captivity

\begin{tabular}{|c|c|c|c|c|c|c|c|c|}
\hline \multicolumn{4}{|c|}{ Transfer (Alive) } & \multicolumn{3}{|c|}{ Data kematian (Dead data ) } & \multirow[b]{2}{*}{$\begin{array}{l}\text { Jenis kelamin } \\
\text { saat mati } \\
\text { Sex at death }\end{array}$} & \multirow[b]{2}{*}{$\begin{array}{c}\text { Jenis kelamin } \\
\text { berdasarkan } \\
\text { EUSA } \\
\text { Sex determi- } \\
\text { nation by } \\
\text { EUSA }\end{array}$} \\
\hline $\begin{array}{l}\text { Tanggal } \\
\text { Date }\end{array}$ & $\begin{array}{l}\text { Penandaan } \\
\text { Tag }\end{array}$ & $\begin{array}{l}\text { Panjang } \\
\text { cagak } \\
\text { Fork } \\
\text { length } \\
\text { (cm) }\end{array}$ & $\begin{array}{c}\text { Bobot } \\
\text { badan } \\
\text { Body } \\
\text { weight } \\
(\mathrm{kg}) ; \\
\mathrm{n}=\mathbf{2 0}\end{array}$ & $\begin{array}{l}\text { Tanggal } \\
\text { Date }\end{array}$ & $\begin{array}{l}\text { Panjang } \\
\text { cagak } \\
\text { Fork } \\
\text { length } \\
\text { (cm) }\end{array}$ & $\begin{array}{c}\text { Bobot } \\
\text { badan } \\
\text { Body } \\
\text { weight } \\
(\mathrm{kg})\end{array}$ & & \\
\hline $7 / 10 / 2009$ & 420B583546 & 79.0 & 8.693 & $12 / 10 / 2009$ & 80 & 8.200 & Jantan (Male) & Jantan (Male) \\
\hline \multirow[t]{4}{*}{ ESA } & 420B535867 & 65.5 & 4.993 & $5 / 7 / 2010$ & 73.0 & 8.620 & Jantan (Male) & Jantan (Male) \\
\hline & 420B5C4B26 & 71.0 & 6.338 & $12 / 12 / 2010$ & 127.0 & 40 & Jantan (Male) & Jantan (Male) \\
\hline & 420B516615 & 82.0 & 9.707 & & & & & Jantan (Male) \\
\hline & $420 B 711 C 74$ & 70.0 & 6.078 & $1 / 8 / 2010$ & 95.0 & 16.650 & Betina (Female) & ) Betina (Female) \\
\hline \multirow[t]{4}{*}{$19 / 11 / 2009$} & 420B4D196D & 45 & 1.644 & & & & & \multirow[t]{2}{*}{ Jantan (Male) } \\
\hline & 420B5E4856 & 54 & 2.820 & $3 / 8 / 2010$ & 85 & 11.85 & Jantan (Male) & \\
\hline & $421354577 \mathrm{~F}$ & 43 & 1.437 & & & & & Jantan (Male) \\
\hline & 420B664B6D & 52 & 2.522 & & & & & Jantan (Male) \\
\hline $7 / 1 / 2010$ & 42103А444F & 75 & 7.454 & $8 / 1 / 2010$ & 73 & 6.650 & Betina (Female) & \\
\hline \multirow[t]{4}{*}{$13 / 2 / 2010$} & 4210486E & 66 & 5.107 & & & & & Betina (Female) \\
\hline & 42135A035E & 80 & 9.023 & & & & & Betina (Female) \\
\hline & 42103E2D48 & 81 & 9.360 & $20 / 11 / 2010$ & 114 & 23 & Jantan (Male) & Jantan (Male) \\
\hline & 42137A0567 & 80 & 9.023 & & & & & Jantan (Male) \\
\hline \multirow[t]{12}{*}{$1 / 3 / 2010$} & 420B6F491A & 59 & 3.665 & $15 / 5 / 2010$ & 65 & 4.600 & $\begin{array}{c}\text { Tidak diketahui } \\
\text { Unknown }\end{array}$ & \\
\hline & 42137C6455 & 67 & 5.339 & & & & & Jantan (Male) \\
\hline & $420 B 462 F 1 A$ & 53 & 2.668 & & & & & Betina (Female) \\
\hline & 42104E4354 & 67 & 5.339 & & & & & Jantan (Male) \\
\hline & 420C1D104A & 66 & 5.107 & & & & & Jantan (Male) \\
\hline & $421038516 F$ & 67 & 5.339 & & & & & Jantan (Male) \\
\hline & 420B47187E & 59 & 3.665 & $10 / 3 / 2010$ & 59 & 4.100 & Jantan (Male) & \\
\hline & 420B712261 & 57 & 3.309 & & & & & Betina (Female) \\
\hline & 42103BAC1D & 56 & 3.140 & & & & & Betina (Female) \\
\hline & $421046506 A$ & 54 & 2.820 & $21 / 5 / 2010$ & 58 & 3.500 & $\begin{array}{c}\text { Tidak diketahui } \\
\text { Unknown }\end{array}$ & \\
\hline & 42104A5954 & 58 & 3.484 & & & & & Jantan (Male) \\
\hline & 4210353463 & 84 & 10.424 & & & & & Jantan (Male) \\
\hline \multirow[t]{4}{*}{$27 / 4 / 2010$} & 420B676431 & 58 & 3.484 & & & & & Betina (Female) \\
\hline & 420B462934 & 59 & 3.665 & & & & & Jantan (Male) \\
\hline & 4210444247 & 69 & 5.824 & & & & & Jantan (Male) \\
\hline & 42137A734D & 58 & 3.484 & & & & & Betina (Female) \\
\hline
\end{tabular}


Lanjutan Tabel 2 (Table 2 continued)

\begin{tabular}{|c|c|c|c|c|c|c|c|c|}
\hline \multicolumn{4}{|c|}{ Transfer (Alive) } & \multicolumn{3}{|c|}{ Data kematian (Dead data ) } & \multirow[b]{2}{*}{$\begin{array}{l}\text { Jenis kelamin } \\
\text { saat mati } \\
\text { Sex at death }\end{array}$} & \multirow[b]{2}{*}{$\begin{array}{c}\text { Jenis kelamin } \\
\text { berdasarkan } \\
\text { EUSA } \\
\text { Sex determi- } \\
\text { nation by } \\
\text { EUSA }\end{array}$} \\
\hline $\begin{array}{l}\text { Tanggal } \\
\text { Date }\end{array}$ & $\begin{array}{l}\text { Penandaan } \\
\text { Tag }\end{array}$ & $\begin{array}{l}\text { Panjang } \\
\text { cagak } \\
\text { Fork } \\
\text { length } \\
\text { (cm) }\end{array}$ & $\begin{array}{c}\text { Bobot } \\
\text { badan } \\
\text { Body } \\
\text { weight } \\
(\mathbf{k g}) ; \\
\mathbf{n = 2 0}\end{array}$ & $\begin{array}{l}\text { Tanggal } \\
\text { Date }\end{array}$ & $\begin{array}{l}\text { Panjang } \\
\text { cagak } \\
\text { Fork } \\
\text { length } \\
\text { (cm) }\end{array}$ & $\begin{array}{c}\text { Bobot } \\
\text { badan } \\
\text { Body } \\
\text { weight } \\
\text { (kg) }\end{array}$ & & \\
\hline & 42102A4617 & 63 & 4.450 & $10 / 8 / 2010$ & 82 & 11.5 & Jantan (Male) & \\
\hline & 4210550F39 & 66 & 5.107 & & & & & Betina (Female) \\
\hline & 42104D7B1C & 72 & 6.606 & $13 / 6 / 2010$ & 72 & 7.35 & Jantan (Male) & \\
\hline & $420 B 545 A 2 C$ & 65 & 4.881 & & & & & Betina (Female) \\
\hline & $42104 \mathrm{~F} 3 \mathrm{D} 2 \mathrm{C}$ & 57 & 3.309 & & & & & Jantan (Male) \\
\hline & 420B48514A & 60 & 3.852 & & & & & Betina (Female) \\
\hline & 420B75460D & 60 & 3.852 & $29 / 10 / 2010$ & 73 & 7.8 & Betina (Female) & \\
\hline & 420B4B530D & 60 & 3.852 & & & & & Jantan (Male) \\
\hline & 420B5C5009 & 61 & 4.045 & $20 / 6 / 2010$ & 65 & 5.2 & Jantan (Male) & \\
\hline & 4210405122 & 67 & 5.339 & $19 / 11 / 2010$ & 85 & 13.6 & Betina (Female) & Betina (Female) \\
\hline & 42103BOF73 & 69 & 5.824 & & & & & Betina (Female) \\
\hline
\end{tabular}

Keterangan (Note):

Induk yang sudah mati di tangki pemeliharaan (Death broodstock in the tank)

Induk yang masih hidup dan teridentifikasi kelamin berdasarkan hasil analisis (Alive broodstock and sex identified)

\section{KESIMPULAN}

Dari hasil analisis dot blot menghasilkan ekspresi vitelogenin tampak jelas pada individu betina dan efek plasma terlihat transparan. Analsisis hormon 11-KT menggunakan klip sirip memberikan hasil yang baik dengan aktivitas hormon terlihat jelas. Induk ikan tuna sirip kuning yang terindentifikasi di tangki pemeliharaan adalah 11 ekor betina dan 15 ekor jantan.

\section{UCAPAN TERIMA KASIH}

Penulis mengucapkan terima kasih kepada Prof. Dr. Haryanti atas masukan dan bantuannya di Laboratorium Bioteknologi pada BBPPBL Gondol. Miss. Ursulla Hoeder dari Heinrinch Heine University Dusseldorf atas metode dan bantuan selama pelaksanaan penelitian.

\section{DAFTAR ACUAN}

Bonn, J.P., van Zanden, J.J., Lewis, W.E., Zegers, B.N., Goksøyr, A., \& Arukwe, A. 2002. The expression of CYP1A, vitellogenin and zona radiata proteins in Atlantic salmon (Salmo salar) after oral dosing with two commercial PBDE flame retardant mixtures: absence of short-term responses. Mar. Environ. Res., 54: 719- 724.

Bon, E., Barbe, U., Núñez Rodriges, J., Cuisset, B., Pelissero, C., Sumpter, J.P., \&Le Menn, F. 1997. Plasma vitellogenin levels during the annual reproductive cycle of the female rainbow trout (Oncorhynchus mykiss): Establishment and Validation of an ELISA. Comparative Biochemistry, 117B(1): 75- 84.

Desantis, S., Corriero, A., Cirillo, F., Deflorio, M., Brill, R., Griffiths, M., Lopata, A.L., de la Serna, J.M., Bridges, C.R., Kime, D.E., \& De Metrio, G. 2005. Immunohistochemical localization of CYP1A, vitellogenin and zona radiata proteins in the liver of swordfish (Xiphias gladiatus L.) taken from the Mediterranean Sea, South Atlantic, South Western Indian and Central North Pacific Oceans. Aquatic toxicology, 71: 1- 12.

Mosconi, G., Carnevali, O., Carletta, R., Nabissi, M., \& Polzonetti- Magni, A.M. 1998. Gilthead Seabream (Sparus aurata) Vitellogenin: Purification, Partial Characterization, and 
Validation of an Enzyme- Linked Immunosorbent Assay (ELISA). General and Comparative Endocrinology, 110: 252- 261.

Sauca, V., Corriero, A., Bridges, V, \& De Metrio, G. 2001. Study of the sexual maturity of female bluefin tuna (Thunnus thynnus): purification and partial characterization of vitellogenin and its use in an enzymeslinked immunosorbent assay. J. Fish. Biol., 58: 815- 831 .
Suhendrata, T. \& Wahyono, M.M. 1987. Kematangan gonada dan perbandingan kelamin ikan cakalang (Katsuwonus pelamis) di perairan teluk Pelabuhan Ratu dan sekitarnya. Jurnal Penelitian Perikanan Laut, (44) :9- 16.

Zairin, M.Jr. 2000. Annual changes in ovarian maturity of female Thai catfish, Pangasius hypophthalmus reared in a culture pond. Biotropia, 15: 48- 57. 